\title{
Economic cycles and environmental crisis in arid southeastern Spain. A historical perspective
}

\author{
A. Sánchez-Picón*, J.A. Aznar-Sánchez, J. García-Latorre \\ Departamento de Economía Aplicada, Facultad de Ciencias Económicas y Empresariales, Universidad de Almería, La Cañada de San Urbano, s/n 04120 Almería, Spain
}

\begin{abstract}
A B S T R A C T
The arid southeast region has been one of the areas with the oldest settlement in the Iberian Peninsula. Despite limitations imposed by lack of water and low soil fertility, a great number of dwellers have settled in this land for three thousand years thanks to its easy access to the commercial paths of the Mediterranean. The area is currently under great territorial and socioeconomic transformation activated by intensive agriculture through greenhouses and irrigation. The history of this territory offers a series of successful and downward cycles determined, from an ecological and economic point of view, by its integration in different stages of the globalization process. Most recently, in the 19th century an intensive deforestation process took place caused by the mining and iron industry. The deep economic and social crisis which followed the declining of this development model brought also about an ecological crisis. In the second half of the 20th century, negative environmental effects have continued and extended to the next generations with problems such as territorial saturation and aquifer depletion that characterize the new intensive agriculture under plastic. The current debate about the sustainability of this developmental model in such vulnerable environment can take advantage of some ecological lessons from the past.
\end{abstract}

\section{Introduction}

We offer here a journey through the history of anthropic pressure in a semiarid region of little more than $20000 \mathrm{~km}^{2}$. We have tried to summarize its ecological history in connection with its economic history. We first examine the limits of organic economies in a dry environment in order to assess whether, in the Ancient World and during the Islamic period, being part of large Mediterranean trade networks created the illusion of overcoming environmental limits for demographic and economic growth. The rise and fall cycles that have characterized the relationship between a peripheral space and the strong currents of economic development represent one of the topics of our work. We have examined what literature tells us about the integration of the Southeast into the economic globalization scene driven by the 19th century European industrialization as well as the environmental effect of increasing human pressure. Finally, we also point out the characteristics of the new agricultural model that has sustained the most recent phase of growth since the second half of the 20th century and how it modified the associated environmental externalities.

* Corresponding author. Tel.: +34 950 015490; fax: +34 950015472.

E-mail address: aspicon@ual.es (A. Sánchez-Picón).

\section{Present-day environment}

The Southeast of the Iberian Peninsula is the most arid region in Europe. In most of this territory precipitation is below $350 \mathrm{~mm}$ per year and many areas receive less than $250 \mathrm{~mm}$. Cabo de Gata, for instance, receives only $170 \mathrm{~mm}$, having the lowest rainfall record in Europe. Precipitation, as well as scarce is very irregular and often comes in the form of torrential events (Lázaro et al., 2001).

In the southern part of the region several mountain ranges reach great heights interspersed with arid valleys and basins. The fluvial network is formed by water courses usually dry (ramblas) similar to the wadis of North Africa. The exception to this rule is the Segura River which originates outside the region in a mountainous area with higher precipitation. Plant communities are dominated by diverse types of bushes usually of small height and low cover.

The main natural resource, from an economic viewpoint, is represented by minerals (silver, lead, iron, etc.). However, minerals and the maritime location of the region have only acted as intermittent economic growth factors when the area has been connected to large external economic networks. In certain periods of history these connections overcame environmental limitations of the area and allowed people to make the most of the comparative advantages or location rent, but at the cost of subjecting a fragile, instable and unpredictable natural environment to huge pressures 
(McNeill, 1992). The Iberian Southeast coincides, almost completely, with two contemporary administrative entities, the autonomous region of Murcia $\left(11313 \mathrm{~km}^{2}\right.$ ) and the province of Almería $\left(8774 \mathrm{~km}^{2}\right.$ ) (Appendix 1).

\section{The limits of organic economies in an arid environment}

Preindustrial societies were based on organic economies whose main energy source depended on the sun. This means that food, fuel and raw materials consumed by humans originated - directly or indirectly - from the process of photosynthesis, i.e. crops, natural pastures, and woods. The development of plants depends on a series of environmental factors that can limit their growth. In the Iberian Peninsula, and especially in the Southeast, the main limiting factor is water. This factor has not only affected the growth of natural vegetation but also of crops. This explains why cereal yields - an essential food in ancient societies - have traditionally been lower in Spain than in Western Europe on average. In turn, the cereal yields in the Iberian Southeast have been - from as far back as our information goes - approximately half of the Spanish average. For the same reason meat production per hectare represented just about $40 \%$ of the country's average (García-Latorre, 2007) mirroring precipitation levels.

The shortage of water resources is also responsible for the scarcity of energy sources, e.g., charcoal and hydraulic power, which were important respectively for preindustrial societies and during the initial phases of industrialization. It is not hard to believe that the agricultural colonization of this region (in the Neolithic period) began very late, around 4000 or 4500 B.C., probably when there was no available land left in neighboring regions. According to Chapman (1990), the reasons for this delay are the marginal environment of the area, its unpredictability and its ecological instability. In other words, its low agriculture capacity and high level of environmental risk. Since the Iberian Southeast climate has not undergone any significant changes in the last 4500 years (Carrión et al., 2010; Pantaleón-Cano et al., 1999, 2003) the aforementioned environmental limitations have strongly conditioned the economic development of the area from prehistoric times.

\section{Preindustrial networks and ecological alterations}

During the Copper and Bronze ages two contemporary societies from pharaonic Egypt appeared in the Southeast of Iberia, the culture of Los Millares (3000-2300 B.C.) and El Argar culture (2300-1500 B.C.). Both were agricultural societies that achieved a considerable level of technological and organizational development, without parallel in Western Europe at the time. Both societies disappeared in a sudden and disastrous way. The environmental disturbances induced by man (deforestation, erosion, loss of soil) seem to have played a decisive role in their disappearance (Castro and Chapman, 1998). After the dramatic collapse of the Argaric culture, southeast Iberia "returned" to simpler ways of life and low population density.

Recovery began around 800 B.C., when the territory came into contact with a large "international" network for the first time, the Phoenician commerce, which operated throughout the Mediterranean. Phoenicians began the large scale exploitation of silver, lead and iron ore in the Southeast, and as an indirect result of this activity founded the first towns in the region (Baira and Abdera, today Vera and Adra). Later, Carthaginians (Phoenicians established in North Africa) took over the area and founded a new city, Cartagena, destined almost exclusively to the exploitation of silver deposits on the arid Murcian coast. From the third century B.C. onwards the region became a part of the biggest political and commercial network that had ever existed in Europe, the Roman Empire.

Thanks to texts written by Greek and Roman authors, we know that the extraction and melting of minerals in southeast Iberia reached unprecedented levels. In the first century B.C. Strabo wrote that 40000 slaves worked in the mines in Cartagena - which had become one of the largest cities in Roman Spain (Strabo,1917-1932). The production figures given by ancient writers are equally impressive.

Nowadays, archeology and other sciences provide information about this economic activity and its environmental consequences. It has been discovered, for example, that the production of lead and silver during the Roman period was only surpassed during the industrial revolution of the 19th century. Between the 1st century B.C. and the 2 nd century A.D. the South of the Iberian Peninsula was responsible for $70 \%$ of the world's lead production (Ferrari et al., 1999; Rosman et al., 1997). The amount of firewood and charcoal needed to melt the minerals must have been impressive.

The mines in Cartagena were not the only ones in the region. In the Vera basin, archaeological research has shown that mining was behind the demographic boom experienced in the area during the Roman period. Around the 2 nd century A.D. population reached the same density existing at the beginning of the 19th century, 30 inhabitants per $\mathrm{km}^{2}$. Anthracological studies have shown that natural vegetation was drastically reduced (Castro and Chapman, 1998). The same happened in Sierra de Gádor range, another mining area with silver and lead deposits exploited by Romans, and where the largest forest fires in 4000 years occurred (Carrión et al., 2003, 2010). From the 3rd century A.D. onwards mining activity ceased. Many cities, Cartagena among them, disappeared or became small towns and the population decreased considerably. For the next 500 or 600 years the Southeast became an irrelevant and poor corner of the Mediterranean again.

The part of the Iberian Peninsula conquered by Arabs in the 8th century, known as "Al-Andalus", underwent great political, economic and social transformations, including the landscape in some regions. Around the 11th century the South and the East of the country were more similar, in every sense, to the Middle East than to Europe. In addition, some parts of Al-Andalus became part of the giant business network of the Islamic world which extended from the Sahara all the way to India and China. As a result of these changes, the Iberian Southeast entered a new phase of economic and demographic growth between the 10th and 12th centuries.

The area was covered by small, intensively cultivated valleys known as "vegas" and "huertas", which in some cases survived until the 20th century. New irrigation technology and a whole series of new cultivated species (palm tree, rice, mulberry tree, orange tree, etc.) contributed to increase the carrying capacity of the area. Some of these species, like the mulberry tree used to feed silk worms, gave rise to specialized industries and created new trade opportunities. All available evidence shows considerable population growth.

At this time, two new major cities appeared in southeast Iberia, Murcia in the 9th century and Almería in the 10th century. Murcia, next to the only important river in the region (the Segura river) was linked to the construction of a complex hydraulic infrastructure which created the largest irrigated area of the region. Almeria on the contrary, placed in the center of a large bay in an extremely arid zone lacking water courses, was unable to feed a numerous population by itself. However, population did grow very rapidly and by the 11 th century the city had almost 40000 inhabitants. In fact, it became one of the biggest cities in the Iberian Peninsula and even in Europe. The expansion of Arab commerce throughout the Mediterranean had a positive effect on Almería. With its magnificent natural port and at a short distance from Africa, Almería became a central point in the business network of the Islamic 
world. It assumed a role as outlet for goods from the Middle East, Africa and the Indian Ocean. It also became an exporter of luxurious silk fabrics and had the largest slave market in the Western Mediterranean. However, the city had to continually import cereals from North Africa to feed its people (García-Latorre, 2007).

Unfortunately we do not have enough information about the environment in SE Iberia during the Islamic period. It is probable that this new phase of growth did not bring about environmental changes as great as those of the Roman period, since mining performed a secondary role and most food and raw materials came from irrigated agriculture. Agriculture was intensive and provided large yields per unit of surface area, but it occupied very little space. Nevertheless, preindustrial cities did exert pressure on surrounding ecosystems because energy demands as firewood was enormous.

The feudal European society experienced a phase of huge growth since the 11th century. This fact and the aggressive nature of the society itself brought about a confrontation with the Islamic world in the Mediterranean. In 1147, Christians from northern Iberian Peninsula along with Italian sailors and merchants, attacked and destroyed Almería. Although Muslims conquered back the city ten years later, Almería lost its central role in Islamic commerce and, as a consequence, its economic activity plunged. At the end of the 15 th century it barely had 5000 inhabitants.

The conquest of SE Iberia by the Christian kingdoms from the north did happen in two phases. Murcia was conquered in the 13th century and Almería in the 15th. The expulsion of Muslims, followed by weak attempts at colonization, resulted in large areas of the Southeast remaining almost deserted for 250 years. Such depopulation periods lasting several centuries are of great interest as they allow us to understand the behavior of natural environments without the human disturbance. In the Iberian Southeast between the 13th and the 16th centuries there was a surprising expansion of plant cover and of wild fauna. However, some ecosystems substantially altered in earlier periods of economic growth never recovered fully. Documents from the 14th to the 18th century show the existence of large woodlands and forest fauna (e.g., bear, roe deer, red deer, lynx) in the region's mountains. In the arid lowlands, savanna-like vegetation used to grow. It was formed by dense bushes, dispersed trees and small Aleppo pine woods. These ecosystems have almost completely disappeared (GarcíaLatorre, 2007).

The demographic recovery in the Iberian Southeast took place during the 17th and 18th centuries, when some political, social, and economic circumstances which made farming difficult since the end of the Middle Ages changed. This time endogenous factors outweighed exogenous ones, as the geopolitical situation of the Mediterranean and North African piracy deactivated the area's location rent until well into the 18th century. There was a typical Malthusian demographic growth based on the clearing of thousands of hectares. Natural vegetation, free from human interference for centuries, had accumulated fertile soil good for dry farming (Pérez-Picazo and Lemeunier, 1984). Thus, between the 16th and 18th centuries population grew at an annual rate of $1 \%$ in the Almería province and $0.55 \%$ in Murcia. These are the highest growth rates in the whole country during this period (the average in Spain at this time was $0.22 \%$, similar to the rest of Europe). Clearings meant a big deterioration of plant cover and most likely triggered erosion. Big wild mammals of the region, like bear and enzebra (a wild equine) disappeared (García-Latorre, 2007). In the second half of the 18th century demographic growth slowed down and in some areas stopped altogether. Toward 1800 population density in the Iberian Southeast, some 20 inhabitants per $\mathrm{km}^{2}$, was still low compared to the European average of around 50 people per $\mathrm{km}^{2}$. However, possibilities for continued growth in an organic economy context were probably exhausted.

\section{The Southeast's entrance into the first globalization: the rise of mining}

An abrupt change in trend took place during the last decades of the 18th century and the beginning of the 19th century. Growth stopped and a series of disasters (yellow fever epidemics in 1804 and 1811, and the war against Napoleon, 1808-1814) accompanied the economic depression caused by the scarcity of harvests, at the beginning of the 19th century. In addition, projects aimed at increasing irrigated lands, like the large hydraulic works ordered by the government in Lorca, were abandoned after the catastrophic destruction of the Puentes dam in 1802. Such event caused over 600 victims, large destructions in crops and huge material damages in the city (Morales-Gil, 2001). Murcia's population decreased by $-2.8 \%$ between 1797 and 1833 while Spain experienced an increase of $4.3 \%$ the same period (Martínez-Carrión, 2002). The impact of yellow fever epidemics in Cartagena, the main sea port of the region, in 1804 and 1810-1812 made population figures drop from almost 50000 in 1798 to slightly over 20000 in 1823 .

In the period 1787-1820 annual growth rate for the whole Southeast was low (0.3\%) especially in Murcia, five times less than Almería (0.1\% vs. $0.5 \%$, respectively). But the 1820 's demographic dynamism was very high, with annual growth rates above $1.6 \%$, on average higher than in the last two centuries and even higher than in the last decade of the 20th century. However, this kind of growth was subject to strong fluctuations throughout the 19th century. At the beginning of the 20th century figures were very low and even negative between 1920 and 1930 and continued weak until 1970, when growth restarted at a rate of over $1 \%$ per year (Fig. 1 ).

The intense growth for about half century until 1877 resulted in a rare increase of human inpact on the environment and its resources. The 800000 people reached that year equaled about 40 inhabitants per $\mathrm{km}^{2}$, much higher than the Spanish average (32). Halfway through the 19th century the Iberian SE, which historically had been subject to so many environmental and institutional limitations, was a relatively populated space in the Spanish context.

A combination of endogenous and exogenous circumstances explains this extraordinary increase, even though integration into international markets acted as the driving force behind the process. Mineral ore demand in industrialized Europe enhanced trade networks established during the second half of the 18th century to exploit barrilla (a vegetable raw material used in the production of caustic soda) which was sold to markets of northern Europe. Lead was one of the fundamental metals in the 19th century industrialization and the catalyst behind the region's rapid integration into the international economic circuit.

Lead supported the rise of private mining in Spain during the 19th century. The exploitation of mineral in Sierra de Gádor (Almería), encouraged by the privatization of the mining sector (laws from 1817 to 1825), brought about a high concentration of mines, foundries, and miners. From the beginning, mineral extraction was accompanied by the development of a large melting industry. The low fusion point of lead and the simple technology allowed for the proliferation of establishments close to the mines. First in Sierra de Gádor (Almería) range and later on in Almagrera (Almería) and Cartagena (Murcia), following new discoveries in the 1840 's. Exports of lead from the 1820's represented one of the most important items in Spain's foreign trade. In some ways, its value made up for the loss of the trade with the American colonies and, according to national export figures, it was the most important export item after wine and oil.

The irruption of Spanish lead in the international market had a huge impact. The 30000 t obtained from the Alpujarra mountains almost equaled British production, at the time the main global producer. As a consequence, global production tripled in a short 


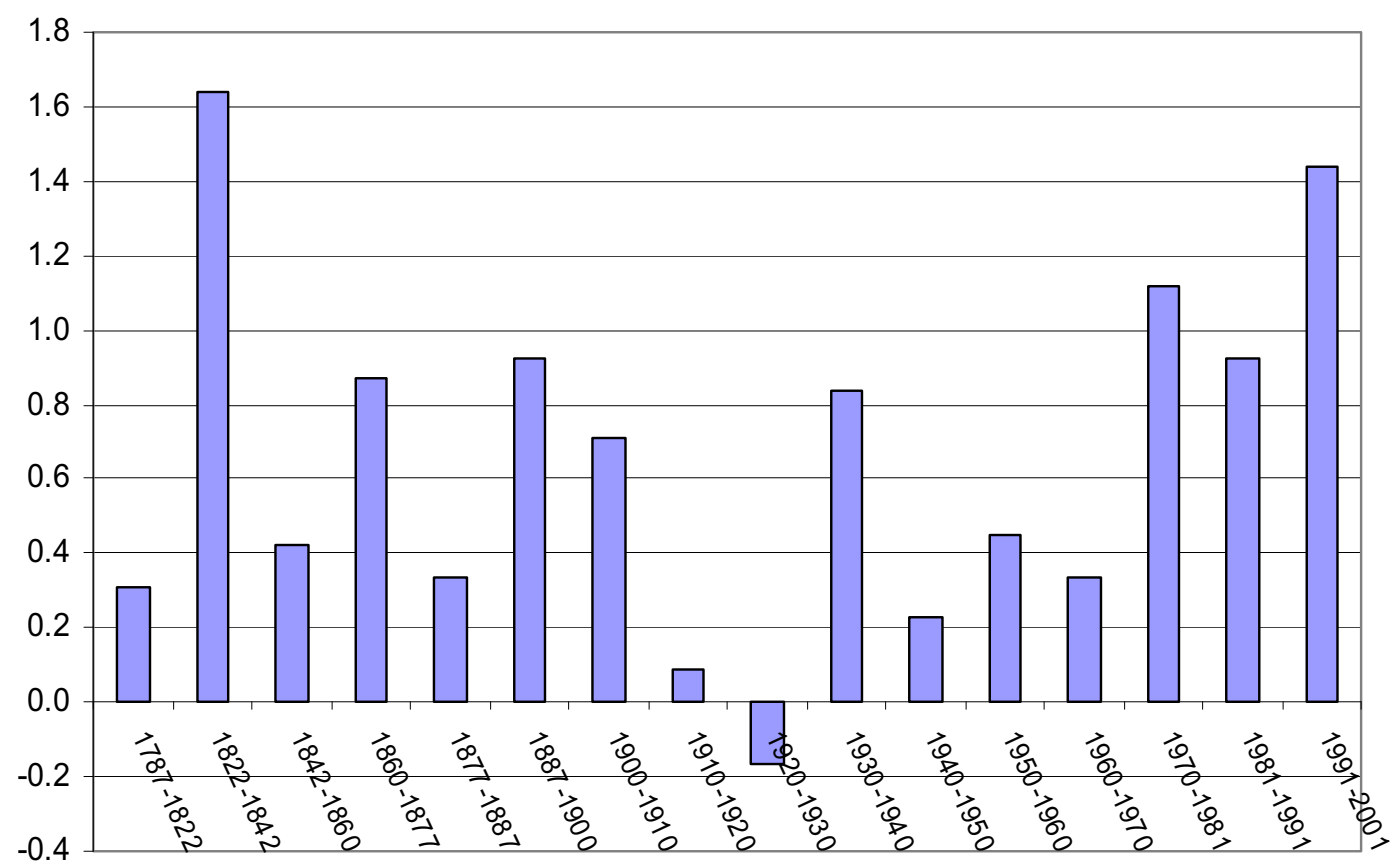

Fig. 1. Average annual growth rate of the population in southeastern Spain (1787-2001). Source: INE, Sánchez-Picón (1992) and Martínez-Carrión (2002).

period of time. This important production increase took place immediately after the liberalization of 1825 . A rule passed this year allowed the private exploitation of Spanish mines, which were previously exclusive property of the Crown. The exhaustion of the British deposits and the contribution of new districts, such as Almagrera and Cartagena during the second half of the century allowed Spain to position itself as the world's main producer for a short time around 1870, just before the rise of the North American mines. Nevertheless, Spain remained in second place until 1920 (Appendix 2).

The Southeast was the greatest contributor to national lead production from mid 19th century until the start of the 20th century, after which other producing areas in Sierra Morena (Jaén and Córdoba provinces) became more important. Whilst globalization progressed, the number of lead producers grew and grew, particularly with the arrival of American and Australian metal and the recovery of German production. Modernization of technology was an absolute must, as was the achievement of scale economies in a less dynamic market than that of the first half of the 19th century. This new situation spelt the end for small, local industries in the Southeast.

The lead decline was slightly compensated between 1890 and 1920 by the development of iron mining, which sprung from planned railways and strong investment of companies with foreign capital. However, this sector barely survived the changes in the iron and steel markets which occurred after World War I.

Despite their vulnerability, the mining cycles reinforced the region's international economic integration. The merchant fleet came to the Spanish Southeast bearing soft British coal and coke and left with their hulls full of metals, minerals and Mediterranean agricultural products. The importing of foreign energy resources was essential following the intense deforestation caused by the "mining fever" experienced during the first few decades of activity (Martínez-Carrión, 2002; Sánchez-Picón, 1996). Moreover, the unusual population growth attracted to mining activities led to the expansion of farming land, dry as much as irrigated, to feed workers (between 15000 and 20000 until the 1880's) and animals (a couple of thousands) used for transport. In addition, further institutional reforms promoted by liberal governments (disentitlement of Church and commons lands) allowed increased plowing of pastures and rolling hills (García-Latorre, 2007; García-Latorre and SánchezPicón, 2001; Martínez-Carrión, 2002; Pérez-Picazo and Lemeunier, 1984; Sánchez-Picón, 1996).

The advance of the "ploughing front" was widespread throughout the arid Southeast and especially in Murcia (PérezPicazo and Lemeunier, 1984). Not only subsistence crops but also commercial ones experienced extraordinary growth. After the phylloxera epidemy, vineyards occupied some 64000 ha in Murcia in 1894, when barely reached 17000 ha in 1870. In Almería the expansion of grape orchards made exports to the British market one of the main sources of wealth in the region until the world war I. Annual shipments reached $50000 \mathrm{t}$ before 1914, produced in 5000 ha situated in narrow valleys in the driest parts of the Southeast. Other irrigated crops such as orange trees expanded under increasing international demand. Esparto grass, a tussockforming species which grew in most of the region's hills, became favorite raw material for the British paper industry in the $1860^{\prime} \mathrm{s}$. Despite regulation attempts, the uncontrolled uprooting of esparto had harmful effects on the region's ecosystems (Sánchez-Picón, 1992).

The expansion of irrigated land caused the complete exploitation of surface water. The construction of dams, diversion dams, and the excavation of galleries allowed for the exploitation of springs and even water that flowed underground beneath the sandy beds of "ramblas" (Pérez-Picazo and Lemeunier, 1990; Sánchez-Picón, 1997). With the adoption of new steam technology (taken from mining) people began to use pumps to lift underground water from much greater depths than they had been able to with traditional water wheels. Very soon, however, a technological block prevented the expansion of irrigated land. As the regenerationist intellectuals pointed out, only the state could guarantee the agricultural growth of a region submerged in a deep social and economic depression. The diffusion of pumping technology in order to access underground aquifers as well as the implementation of huge hydraulic works managed by the State became essential points in the so-called "hydraulic question". Its 
Table 1

Irrigated land in the Southeast of Spain (1916-2000) (in hectares).

\begin{tabular}{|c|c|c|c|c|c|c|}
\hline & \multicolumn{2}{|l|}{ Almería } & \multicolumn{2}{|l|}{ Murcia } & \multicolumn{2}{|c|}{ Southeast } \\
\hline & ha & Índex & ha & Índex & ha & Índex \\
\hline 1916 & 26350 & 100 & 57478 & 100 & 83828 & 100 \\
\hline 1935 & 32745 & 124 & 68000 & 118 & 100745 & 120 \\
\hline 1962 & 36252 & 138 & 83250 & 145 & 119502 & 143 \\
\hline 1978 & 57300 & 217 & 136700 & 238 & 194000 & 231 \\
\hline 2000 & 64849 & 246 & 191053 & 332 & 255902 & 305 \\
\hline
\end{tabular}

Source: Junta Agronómica (1918), Sánchez-Picón (1997) and Martínez-Carrión (2002).

objective was, on one hand, regulate fluvial courses to avoid catastrophic inundations and, on the other hand, guarantee irrigation for commercial crops. In the basin of the Segura River in Murcia, the construction of a series of reservoirs between 1917 and 1933 allowed for the expansion of irrigated lands to grow from 57000 ha to more than 68000 ha. In Almería, however, the growth block persisted until the second half of the 20th century (Table 1 ).

The crisis of the first cycle of globalization was brought about by the fall in mineral and traditional agricultural product prices from 1880 onwards. Spain's Southeast had to face its physical limitations again. Newly plowed lands experienced diminishing returns which could only be counteracted by importing industrial goods and energy resources which became more costly while farming was rapidly losing profitability.

The agricultural and mining crises created the need for severe change. The once densely populated region had to resort to emigration. By the end of the 19th century, the Southeast of the Iberian Peninsula became, and until the 1970's, one of the main sources of emigration in Spain (Fig. 2). Migrants made their way to more industrialized parts of Spain (mostly Catalonia), to Algeria (from 1870 onwards), Latin America (from 1900 onwards) and Europe - Germany, France, and Switzerland - (from 1950 onwards). The migratory balance was negative until the 1980's when the demand for workers in the intensive agriculture sector, the development of tourism and real estate, and the modernization of the Spanish economy reversed the migratory trend. Economical changes after the 1980's were fostered by the integration of Spain in the European Economic Community, as well as by tourism and construction growth. All this had a considerable impact on the Spanish Southeast and the region became recipient of a large volume of African, European, and Latin American immigrants (Aznar-Sánchez, 2000).

\section{A new agricultural model as a base for economic growth: the southeast in the second globalization}

In the second half of the 20th century, one of the largest agrarian transformations in Spain's recent history took place in the Southeast of the country: the introduction and subsequent development of vegetable production using plastic greenhouses. This new agricultural model, which represented a departure from previous farming systems, was established in a new location and was entirely dependent on subterranean water sources. Compared with existing models, the farming methods are different, the technology is novel, and new leading economic agents are emerging.

This model owed its introduction to the following production factors (Ferraro-García, 2000). (1) Natural resources. The warm microclimate of the region is suitable for growing horticultural crops (e.g., minor temperature change between day and night, high sunshine hours, low humidity, and rare frosts), and there was abundant underground water and inexpensive land. (2) Technology. A new technique, "enarenado" (the creation of an artificial soil) was employed, which enabled farming in areas with lowquality, saline water, accelerating the maturity of the crops. (3) Institutions. The Instituto Nacional de Colonización (INC, created in 1939 with the aim of advancing the Spanish agrarian sector) provided electrical and hydraulic infrastructure, technical advice, and funding, as well as promoting tenant farmer settlements. (4) Labor. A young workforce was available with a high capacity for work and a low aversion to risk, as there were few employment alternatives other than emigrating to find work. (5) Markets. There existed an expanding European fruit and vegetable market, with a high demand for out-of-season vegetables.

Initially, the intensive agriculture model was based on these factors. However, continued growth and development depended on the constant evolution of production systems, innovation, and commercialization. As a result, and notably since the widespread production of vegetables in the 1960s, farming techniques have continued to evolve. Today, there remains an enduring amalgamation of innovations that have improved the productivity and quality of products, and have even prolonged the growing season. Accordingly, intensive agriculture is a dynamic system that is

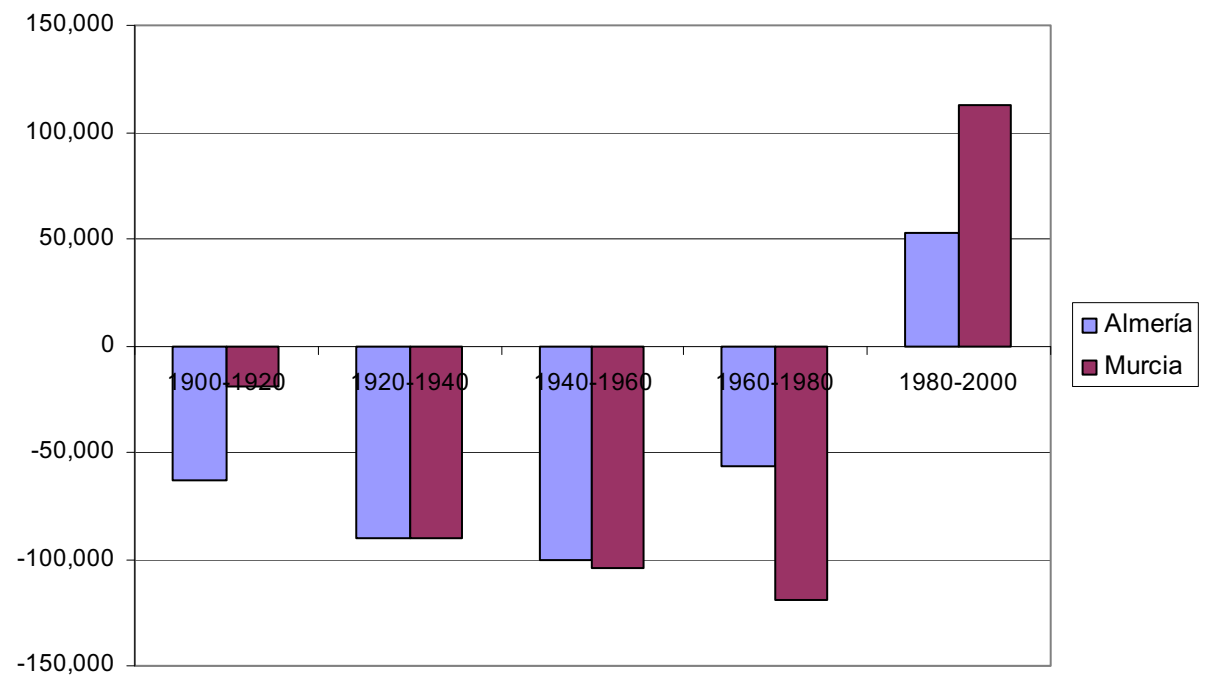

Fig. 2. Migratory trends in the Southeast of Spain in the 20th century. Elaborated from Alcaide (2003). 
institutionally and technologically complex. The system of using semi-artificial soil protected with a polythene cover requires significant concentrations of water, agricultural chemicals, and manpower; however, greenhouses enable earlier crop maturity and harvests compared with the rest of Spain and Europe, and production can continue throughout the winter months without the need for costly heating systems (as used elsewhere in Europe; e.g., the Netherlands). Furthermore, this system produces higher yields and product quality, a longer plant cycle, and enables two (sometimes three) harvests a year. The term "forced crops" is often applied to this type of farming. Agricultural styles of this nature bear a closer resemblance to an industrial production system than to a traditional agricultural one, having high consumption levels of industrial supplies, a large workforce, and sophisticated technology (Molina-Herrera, 2005).

The economic model based on this system of agriculture has brought about rapid economic and population growth in southeast Spain (especially in Almería), the likes of which have not been seen in Spain's recent economic history. The socioeconomic change stimulated by this agricultural sector has been of such magnitude that it has become been referred to as "miraculous" (Downward and Taylor, 2007; González-Olivares and González-Rodríguez, 1983; Mota et al., 1996; Tout, 1990). Until the end of the 1960s, southeast Spain was categorized as an "underdeveloped" region, with one of the lowest GDP rankings in Spain. However, the area began to experience high growth levels following the introduction and subsequent development of intensive agriculture, eventually occupying a middle ranking for GDP. At the same time, the population of southeast Spain has grown at such a spectacular rate that it has become the Spanish region boasting the greatest growth in population and immigration in recent years (Aznar-Sánchez et al., 2009).

Traditionally, the most prosperous agricultural areas in southeast Spain produced irrigated fruit and vegetables in riverbeds, in the Segura, Andarax, and Almanzora regions (Pérez-Picazo and Lemeunier, 2003). However, new agricultural activity is concentrated in the coastal area that stretches between the municipal districts of Adra and Nijar in Almería, and the coastal regions of Mazarrón, Aguilas, and Cartagena in Murcia. These districts accommodate 40000 ha of greenhouses, which represent $65 \%$ of the greenhouse areas in Spain and more than $40 \%$ of the Mediterranean total (Cotec, 2009). Many of these areas were originally uncultivated because they were not suitable for growing fruit trees or other species (Calvo García-Tornel, 2006). The low-quality soil meant that the land remained unproductive for many years, resulting in a fall in land values, which then enabled farmers to purchase their own property. In the space of several years, the land went from being a "desert" (Fernández-Lavandera and Pizarro-Checa, 1981) to the "vegetable patch of Europe" (Camacho-Ferre, 2002). The area produces over 4 million tonnes of vegetables ( $70 \%$ of the national total), the majority of which is destined for the European market.

The Campo de Dalias zone is an excellent example of this type of agriculture. This area contains $50 \%$ of the greenhouse hectares in southeast Spain (more than 18500 ha of the 39000 ha in the zone is occupied by greenhouses), and has one of the largest concentrations of greenhouses in the world. This development has been one of the greatest territorial transformations in Europe in the latter third of the 20th century (Appendix 3).

In Almería, the use of subsoil water in irrigation is a longestablished and dominant practice. The lack of surface resources prompted the province to pioneer the pumping of underground water. The Agricultural Inventory of 1916 states that a third of the irrigated land (some 26300 ha in total) first depended on aquifers (Sánchez-Picón, 1997). By the end of the 20th century, farmers were almost fully dependent on subsoil water for irrigation, with almost $80 \%$ of all irrigated terrain water sourced in this manner. In Murcia, despite a large investment in the regulation of surface water by the construction of a network of reservoirs and, most significantly, the importing of water into the region following the establishment of the Tajo-Segura diversion in 1978, the degree of dependency on underground aquifers continues to increase.

The new intensive agriculture model is characterized as being dependent on underground water. In the quest to extract water, continued promotion of technological advances by the INC has enabled access to underground aquifers. From the 1950s onward, the INC began work on an elaborate network of wells and water distribution systems that have led to the substantial use of underground water today. The continued growth in the number of greenhouses in the 1980s and 1990s placed a huge demand on the water supply; however, because of its underground origin, the remaining supply is difficult to measure. The impact of this demand became apparent when the quality of water from the aquifers began to show noticeable deterioration (decreased piezometric levels and increased salinization levels in coastal areas) prompting the sector to optimize and conserve its use of water (Consejería de Agricultura y Medio Ambiente, 1991; Martínez-Fernández and Esteve-Selma, 2002; Pulido-Bosch et al., 2000; Sánchez-Martos et al., 2002; Tout, 1990).

Nationwide, irrigation in the Southeast of Spain is currently the most technologically advanced and efficient, predominantly using trickle irrigation (Colino-Sueiras and Martínez-Paz, 2002). Furthermore, the water deficit issue has been significantly addressed with the passing of the Hydrological Plan for the Southern Basin Area and the AGUA program (Downward and Taylor, 2007; Ferraro-García, 2000; López-Gálvez and LosadaVillasante, 1999, 2001). Measures have been taken to increase the water supply (river diversions, desalination plants, small dams, and reuse methods) and to connect the entire system via a "water highway". In terms of demand, measures have been undertaken to improve the collection and use of rainwater (Gómez-Orea, 2003). The capacity and evolution of the aquifers is being studied with the aim of establishing a suitable regulatory framework. At the same time, increased water prices have enabled complete recovery of investment in and maintenance of the hydraulic infrastructure, as required by the "Directive Framework for Water" (García-Torrente, 2005). These measures have brought about a significant reduction in water needs and have decreased the pressure placed on aquifers in southeast Spain.

The management models used in water and irrigation policy throughout the 20th century have been subject to intense discussion. The so-called "new water culture" proposes the preservation of all surface and underground aquifers as common heritage and the establishment of controls on demand, with the aim of limiting unsustainable growth in the demand for water (Arrojo-Agudo, 2001).

Intensive agriculture generates new environmental and territorial externalities for two reasons: first, it produces waste (e.g., organic and plastic waste, and containers); and second, the sector has been developed with insufficient territorial planning and supervision by the involved administrators. The result was rapid growth from the 1970s onward that occurred in a haphazard and unstructured manner, creating significant negative externalities: the exploitation and contamination of aquifers; extraction of sand and soil for agricultural use; unregulated removal of waste; occupation of areas of environmental interest; deterioration of the landscape; use of public waters; a badly structured and ill-managed territorial system; and poor-quality roads (Escobar-Lara, 1998; Gómez-Orea, 2003; Mota et al., 1996). Furthermore, the development of intensive agriculture created competition with other economic activities, such as tourism, for the use of natural resources. This is the case in El Ejido, Roquetas de Mar, and Aguilas, 
where a significant concentration of greenhouses and growing tourist activity for the use of territory and natural resources such as water and even sand.

However, action has been taken from the mid-1990s to remedy these negative externalities: the unregulated extraction of sand and soil has ceased due to the establishment of a penalty system, the undertaken surveillance, resources can only be extracted from controlled quarries and "no soil" farming (hydroponic farming) has gradually been introduced (Gómez-Orea, 2003). In addition, various rural hygiene plans been put in place for the collection and suitable disposal of waste (Escobar-Lara, 1998). Biological control techniques have been implemented to manage crop plagues, and farmers are becoming increasingly aware of the need to maintain a healthy environment. The authorities have also increased their awareness of and involvement in environmental issues (Fundación Cajamar, 2009). Consequently, many of the imbalances mentioned above are being addressed and a gradual internalization of environmental and territorial costs is occurring (Galdeano-Gómez et al., 2008). In addition, it appears that the high concentration of greenhouses in the Spanish Southeast has a positive effect in the fight against climate change (Campra et al., 2008).

The agricultural sector has grown substantially over time to make the most of its position in the European market. Nonetheless, recent changes in the agricultural food system, in both the European and global markets, have given rise to threats that could shape the sector's future. There now exist a large number of suppliers, representing a possible threat to the success of the industry, especially under the increasingly concentration of distribution channels (Pérez-Mesa, 2007). In contrast, on a global scale, the changing international market is becoming increasingly globalized and competitive (Aznar-Sánchez, 2006).

The above threats to the agricultural sector, among others, are known from earlier expansion cycles in southeast Spain. Although it echoes earlier models of the exploitation of natural resources, the current model of development has a number of dynamic and systemic advantages due to the setup of the local production system for intensive horticulture (Aznar-Sánchez and GaldeanoGómez, 2010; Aznar-Sánchez and Sánchez-Picón, 2010). EU regulations have had a positive effect on the dynamics of this local productive system, guaranteeing free access to the European market as well as limiting the importation of non-community products. Furthermore, subsidies have been granted to farmers to help offset the costs of structural reform related to traceability, certification and waste tracking (Galdeano-Gómez et al., 2011). The present expansion cycle is distinguished from those of previous eras by the accumulation of knowledge, technology, and capital, as well as the predominantly endogenous character which have enabled the development of the model beyond its initial fostering factors (Aznar-Sánchez et al., 2011). Nevertheless, a number of limitations threaten the future growth rate and viability of this model of development: most significantly, its effects on natural resources and the environment, and a lack of territorial planning.

\section{Conclusions}

The extreme dryness of the Iberian Southeast is a considerable environmental obstacle to the development of economic and residential growth. However, during certain times in history, participation in world economic networks has enabled the region to overcome its environmental limitations and to benefit from its comparative advantages and location. Such development comes at an environmental cost and places immense pressure on natural resources.

By the 19th century, this area had already surpassed the economic and demographic threshold that for hundreds of years had placed a Malthusian limit on its development. Therefore, as in other periods in history, its integration into an international trade network created essential incentives and resources for growth. The integration of southeast Spain into the first globalization networks (1850-1914), as well as institutional changes brought about by the liberal legislation of the Spanish Government, acted as powerful incentives for increases in both population and economic growth. This rapid rise resulted in economic, social, and environmental vulnerabilities.

The failure of the first integration into the global economy led southeast Spain to experience a period of relative regression compared with other developed regions in both Spain and Europe. From the 1960s onward, however, opportunities for recovery came in the form of agriculture and tourism. For the past 30 years, the region has been described as the "vegetable patch of Europe". Here, we can find the world's highest concentration of intensive agriculture under plastic, supplying fruit and vegetables to a significant proportion of the European market.

This new development model has resulted in intense territory changes. Expansive urbanization has covered the best agricultural land of the region in cement and tar, while the new agricultural model is situated on poor, rocky, coastal land. The production cycles have been entirely separated from natural cycles, and the environmental, social, and economic functions of the traditionally irrigated lands of the Mediterranean have disappeared (e.g., biodiversity, landscape variety, and the conservation of fertile soil). The new production model has forced a spiral of instability; in the case of newly irrigated lands, this is in the form of pollution via the use of pesticides and fertilizers, and the exploitation of aquifers. Regional planning, based on environmental, social, and economic stability, is a priority in guaranteeing the future of those who live in the driest place in Europe.

\section{Acknowledgments}

This research has been carried out thanks to HAR2010-21941C03-03 and ECO2008-02258 projects funded by the Spanish Ministerio de Ciencia e Innovación and Fondo Europeo de Desarrollo Regional aid. This paper has benefited by changes suggested by Francisco I. Pugnaire, Consejo Superior de Investigaciones Científicas (CSIC), Spain, and two anonymous referee on an earlier draft.

\section{Appendix. Supplementary data}

Supplementary data related to this article can be found online at doi:10.1016/j.jaridenv.2010.12.014

\section{References}

Alcaide, J., (Dir.), 2003. Evolución económica de las regiones y provincias españolas en el siglo XX. Fundación BBVA, Madrid.

Arrojo-Agudo, P., (Coord.), 2001. El Plan Hidrológico Nacional a debate. Bakeaz/ Fundación Nueva Cultura del Agua, Bilbao.

Aznar-Sánchez, J.A., 2000. Dinámica demográfica y económica de Almería en el siglo XX. Universidad de Almería, Almería.

Aznar-Sánchez, J.A., 2006. La competencia entre la horticultura intensiva de Marruecos y España. Thomson-Civitas, Navarra.

Aznar-Sánchez, J.A., et al., 2009. Análisis de la inmigración en la provincia de Almería. Dirección General de Coordinación de Políticas Migratorias, Sevilla.

Aznar-Sánchez, J.A., Sánchez-Picón, A., 2010. Innovación y distrito en torno a un milagro: la configuración del sistema productivo local de la agricultura intensiva de Almería. Revista de Historia Industrial 42, 157-193.

Aznar-Sánchez, J.A., Galdeano-Gómez, E., 2010. Territory, cluster and competitiveness of the intensive horticulture in Almería (Spain). The Open Geography Journal 3, 269-280.

Aznar-Sánchez, J.A., Galdeano-Gómez, E., Pérez-Mesa, J.C. , 2011. Intensive horticulture in Almería, Spain: a counterpoint to current European rural policy strategies. Journal of Agrarian Change 11 (2).

Calvo García-Tornel, F., 2006. Sureste español: regadio, tecnologías hidraulicas y cambios territoriales. Scripta Nova 10, 218. 
Camacho-Ferre, F., (Coord.), 2002. España, huerta de Europa. Ministerio de Agricultura, Pesca y Alimentación, Madrid.

Campra, P., García, M., Canton, Y., Palacios-Orueta, A., 2008. Surface temperatura cooling trends and negative radiative forcing due to land use change toward greenhouse farming in southeastern Spain. Journal of Geophysical Research Atmospheres 113, D18109. doi:10.1029/2008JD009912.

Carrión, J.S., et al., 2003. Fire and grazing are contingent on the Holocene vegetation dynamics of Sierra de Gádor, southern Spain. The Holocene 13, 839-849.

Carrión, J.S., et al., 2010. The historical origins of aridity and vegetation degradation in southeastern Spain. Journal of Arid Environments 74, 731-736.

Castro, P.V., Chapman, R.W., 1998. Aguas Project. Plalaeoclimatic Reconstruction and the Dynamics of Human Settlement and Land-use in the Area of the Middle Aguas (Almería), in the South-east of the Iberian Peninsula. European Commission. Environment and Climate Program, Luxemburgo.

Chapman, R.W., 1990. Emerging complexity: the later prehistory of south-east Spain, Iberia and the west Mediterranean. Cambridge University Press, Cambridge.

Colino-Sueiras, J., Martínez-Paz, J.M., 2002. El agua en la agricultura del sureste español: productividad, precio y demanda. Mediterráneo Económico 2, 199-221.

Consejería de Agricultura y Medio Ambiente., 1991. Recursos naturales y crecimiento económico en el Campo de Dalías. Agencia de Medio Ambiente, Sevilla.

Cotec, 2009. Documento sobre oportunidades tecnológicas. Invernaderos de plástico. Fundación Cotec para la Innovación Tecnológica, Madrid.

Downward, S.R., Taylor, R., 2007. An assessment of Spain's programa AGUA and its implications for sustainable water management in the province of Almería southeast Spain. Journal of Environmental Management 82 (2), 277-289.

Escobar-Lara, A., 1998. Aspectos medioambientales de la agricultura en invernaderos. In: Curso Superior de Especialización sobre tecnología de invernaderos, Almería. Consejería de Agricultura y Pesca, FIAPA, Caja Rural de Almería, pp. 71-93.

Fernández-Lavandera, O., Pizarro-Checa, A., 1981. Almería: la técnica del enarenado transforma un desierto. Revista de Estudios Agrosociales 115, 31-70.

Ferrari, Ch., et al., 1999. Ice archives of atmospheric pollution from mining and smelting activities during antiquity. In: Young, et al. (Eds.), Metals in Antiquity. BAR International Series, 792, pp. 211-216.

Ferraro-García, F.J., (Dir.), 2000. El sistema productivo almeriense y los condicionamientos hidrológicos. Civitas, Madrid.

Fundación Cajamar., 2009. Análisis de la campaña hortícola de Almería. Cajamar, Almería.

Galdeano-Gómez, E., Céspedes-Lorente, J., Martínez-del-Río, J., 2008. Environmental performance and spillover effects on productivity: evidence from horticultural firms. Journal of Environmental Management 88, 1552-1561.

Galdeano-Gómez, E., Aznar-Sánchez, J.A., Pérez-Mesa, J.C., 2011. The complexity of theories on rural development in Europe: an analysis of the paradigmatic case of Almería (South-east Spain). Sociologia Ruralis 51 (1), 54-78.

García-Latorre, J., 2007. Almería: hecha a mano. Una historia ecológica. Fundación Cajamar, Almería.

García-Latorre, J., Sánchez-Picón, A., 2001. The man-made desert: effects of economic and demographic growth on the ecosystems of arid southeastern Spain. Environmental History 6 (1), 75-94.

García-Torrente, R., 2005. El sector agrario. In: Molina-Herrera, J. (Dir.), La economía de la provincia de Almería. Cajamar, Almería, pp. 153e208.

Gómez-Orea, D., 2003. La horticultura en Almería. Bases para un Plan de Ordenación Territorial y Gestión Medioambiental. Cajamar, Almería.

González-Olivares, F., González-Rodríguez, J., 1983. Almería: el milagro de una agricultura intensiva. Papeles de Economía Española 16, 152-168.

Junta Agronómica, 1918. Medios que se utilizan para suministrar el riego a las tierras. Distribución de los cultivos en la zona regable, Ministerio de Fomento Madrid.

Lázaro, R., Rodrigo, F.S., Gutiérrez, L., Domingo, F., Puigdefábregas, J., 2001. Analysis of a 30-year rainfall record (1967-1997) in semi-arid SE Spain for implications on vegetation. Journal of Arid Environments 48, 373-395.
López-Gálvez, J., Losada-Villasante, A., 1999. Evolución de las técnicas de riego en el sudeste de España. In: Garrabou-Segura, R., Naredo-Pérez, J.M. (Eds.), El agua en los sistemas agrarios. Una perspectiva histórica. Fundación Argentaria, Madrid, pp. $427-445$.

López-Gálvez, J., Losada-Villasante, A., 2001. Gestión del agua de riego en el Campo de Dalías. In: Hernández-Mora, N., Ramón-Llamas, M. (Eds.), La economía del agua subterránea y su gestión colectiva. Fundación Marcelino Botín, Madrid, pp. 367-404.

Martínez-Carrión, J.M., 2002. Historia Económica de la Región de Murcia. Editora Regional, Murcia.

Martínez-Fernández, J., Esteve-Selma, M.A., (Coords.), 2002. Agua, regadío y sostenibilidad en el Sudeste ibérico. Bakeaz, Bilbao.

McNeill, J.R., 1992. The Mountains of the Mediterranean World: An Environmental History. Cambridge University Press, Cambrigde.

Molina-Herrera, J., (Dir.), 2005. Claves para la interpretación del modelo económico de la provincia de Almería. In: Molina-Herrera, J. (Dir.), La economía de la provincia de Almería. Cajamar, Almería, pp. 13e41.

Morales-Gil, A., 2001. Agua y territorio en la Región de Murcia. Fundación Centro de Estudios Históricos e Investigaciones Locales Región de Murcia, Murcia.

Mota, J.F., Peñas, H., Castro, H., Cabello, J., 1996. Agricultural development vs. Biodiversity conservation: the Mediterranean semiarid vegetation in El Ejido (Almería, southeastern Spain). Biodiversity and Conservation 5 (12), 1597-1617.

Pantaleón-Cano, J., et al., 1999. Evolución del paisaje vegetal en el sudeste de la Península Ibérica durante el Holoceno a partir del análisis polínico. SaguntumPlav 2, 17-24.

Pantaleón-Cano, J., et al., 2003. Palynological evidence for vegetational history in semiárid areas of the western Mediterranenan (Almería, Spain). The Holocene 13 (1), 109-119.

Pérez-Picazo, M.T., Lemeunier, G., 1984. El proceso de modernización de la región de Murcia. Editora Regional de Murcia, Murcia.

Pérez-Picazo, M.T., Lemeunier, G., 1990. Agua y modo de producción. Crítica, Barcelona.

Pérez-Picazo, M.T. Lemeunier, G, 2003. Los sistemas agrarios de la región murciana durante medio milenio (1500-2000). In: Esteve, M., Lloréis, M., Martínez, C. (Eds.), Los recursos naturales de la región de Murcia: un análisis interdisciplinar. Universidad de Murcia, Murcia, pp. 173-195.

Pérez-Mesa, J.C., 2007. Should Almería (Spain) have to worried, thinking that their tomato export is currently affected by international competition? Agricultural Economics Review 8 (2), 42-54.

Pulido-Bosch, A, Pulido-Lebeuf, P. Molina-Sánchez, L, Vallejos, A, MartinRosales, W., 2000. Intensive agricultura, wetlands, quarries and water management. A case study (Campo de Dalias, SE Spain). Environmental Geology $40,163-168$

Rosman, K., et al., 1997. Lead from Carthaginian and Roman Spanish mines isotopically identified in Greenland ice dated from 600 B.C to 300 A.D. Environmental Science \& Technology 31 (12), 3413-3416.

Sánchez-Picón, A., 1992. La integración de la economía almeriense en el mercado mundial (1778-1936). Instituto de Estudios Almerienses, Almería.

Sánchez-Picón, A. (Ed.), 1996. Historia y medio ambiente en el territorio almeriense. Universidad de Almería, Almería.

Sánchez-Picón, A., 1997. Los regadíos de la Andalucía árida (siglos XIX y XX) Expansión, bloqueo y transformación. Áreas 17, 109-128.

Sánchez-Martos, F., Pulido-Bosch, A., Molina-Sánchez, L., Vallejos-Izquierdo, A. 2002. Identification of the origin of salinization in groundwater using minor ions (Lower Andarax, Southeast Spain). The Science of the Total Environment 297, 43-58.

Strabo, 1917-1932. Vol. III. The Geography of Strabo, 8 vol. Harvard University Press and Heinemann.

Tout, D., 1990. The horticultura industry of Almería province, Spain. The Geographical Journal 156 (3), 304-312. 